\title{
LITERATURE AND REVOLUTION
}

\section{A Critical Study of the Writer and Communism in the Twentieth Century}

Jurgen Ruhle * Translated and edited by Jean Steinberg

After World War I, many writers turned to Russia in the hope of a new and better world. But with Stalin's ascent to power, the outbreak of another savage war, and the imposition of Soviet rule on conquered countries, hope changed to fear. In this brilliant study, Jurgen Ruhle, a noted German political commentator and literary critic, examines the work of writers such as Pasternak, Brecht, Mann, Gorky, Sholokhov, Silone, Malraux, Hemingway, Neruda, Lorca, and Tagore in this invaluable discussion of the relationship between totalitarianism and the writer. "A major critical feat . . . indispensable."-Library Journal. 488 pp., bibliog., index

$\$ 12.50$

\section{RUSSIA'S UNDERGROUND POETS}

Edited by Keith Bosley

Introduction by Janet Sapiets

During the past forty years, Soviet writers have been faced with a clearly defined choice: to conform and be accepted, or to rebel and become outcasts. Those who are convinced that they are the true heirs to Russia's artistic legacy publish their works at home and abroad in defiance of all attempts to stop them. The poems in this volume, selected from a variety of underground publications, celebrate life rather than Socialist Realism. The forty-one poets represented-including Pasternak, Okudzhava, Slutsky, Akhmadulina, and Brodsky-can be admired both for their work and for their stubborn courage. $120 \mathrm{pp}$.

\section{PRAEGER PUBLISHERS}

111 Fourth Avenue/New York 10003 


\section{FORTHCOMING}

Contributions scheduled for the March 1970 issue:

Martin A. Miller, "Ideological Conflicts in Russian Populism: The

Revolutionary Manifestoes of the Chaikovsky Circle, 1869-1874"

Deborah Hardy, "Tkachev and the Marxists"

Natalia M. Kolb-Seletski, "Gastronomy, Gogol, and His Fiction"

Richard Mills, "The Formation of the Virgin Lands Policy"

John H. Hodgson, "The Finnish Communist Party"

William E. Harkins, "A Note on the Use of Narrative and Dialogue in War and Peace"

Scheduled for the June 1970 issue:

DISCUSSION

Leszek Kolakowski, "The Fate of Marxism in Eastern Europe"

Comments by Cyril E. Black and Aleksander Gella

\section{Notice}

Unsolicited manuscripts must be accompanied by a self-addressed, stamped envelope.

The Editor, Slavic Review

Thomson Hall

University of Washington

Seattle, Washington 98105 


\title{
ATHERTON PRESS
}

\author{
70 Fifth Avenue, New York, N.Y. 10011
}

\section{JUST PUBLISHED:}

\section{THE LIFE AND DEATH OF SOVIET TRADE UNIONISM: 1917-1928}

\section{Jay B. Sorenson SMITH COLLEGE}

This book, the first definitive study of the relation between the Soviet trade unions and the Party, examines in depth the dilemma of organized labor and political dictatorship.

Contents:

1. On the Threshold; 2. The Dilemma of Power; 3. Round Two: The Affiliated Unions; 4. Industrial Relations: 1917-1921; 5. The Union Question Internalized: Political Fragmentation; 6. The Union Question Internalized: Dictatorship Within the Party; 7. An Ethic of Work; 8. The Party, Unions, and Dictatorship; 9. The Social Problem; 10. Unions, Leaders, and Members: Bureaucracy and Membership Rift; 11. Union Performance, Economic Backwardness; 12. Unions and the Succession Question; 13. Conclusion. Notes. Bibliography. Index.

1969. 295 pp. $\$ 9.50$

\section{Also from Atherton}

\section{THE SOVIET SYSTEM AND MODERN SOCIETY George Fischer COLUMBIA UNIVER\$ITY}

This book takes issue with current assumptions that societies developing an advanced, fully modern economy and culture must inevitably adopt Western-type social and political institutions. The newness of the data reinforces the freshness of the author's approach. The result is a book of value to all scholars and students dealing with the social and political systems of both developing and advanced societies.

1968. 215 pp. $\$ 8.50$

\section{SCIENCE AND IDEOLOGY IN SOVIET SOCIETY George Fischer Editor COLUMBIA UNIVERSITY}

An important contribution to inform readers in the English-speaking world about the very important developments that have been taking place in the broad area of social science in the Soviet Union. . . . An intellectual development of the first importance that deserves careful attention on the part of Western social scientists and intellectuals. -Talcott Parsons Harvard University

1967. 190 pp. $\$ 7.95$

\section{INTERNATIONAL COMMUNISM AND AMERICAN POLICY} Bernard S. Morris INDIANA UNIVERSITY

An excellent book. . . Extremely useful in undergraduate teaching. I know of nothing like it that analyzes this particular aspect of the problem so well.--James S. Magee Grinnell College 1966. 192 pp. Cloth: $\$ 5.95$. Paper: $\$ 2.95$ (for class adoption only)

\section{MARXISM}

\section{Michael Curtis Editor RUTGERS UNIVERSITY}

\section{Ready in January}

This book covers the wide range of basic issues and problems arising from what has been said for, against, and about Marxism. A rich and systematic collection of writings, it provides the most inclusive and up-to-date analysis of Marxist thought available today. 1970. 352 pp. $\$ 6.95$

Twenty percent professional discount and free postage and handling on all orders accompanied by check or money order. New York State residents: please add local tax. 